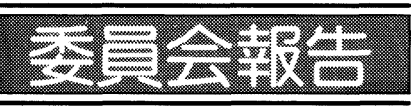

\title{
乱流における組織構造の役割
}

\section{THE ROLE OF COHERENT STRUCTURES IN TURBULENT FLOW}

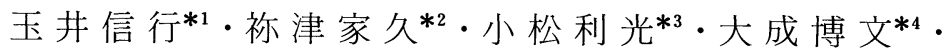 \\ 大橋正和 ${ }^{* 5} \cdot$ 浅枝隆*6 \\ By Nobuyuki TAMAI, Iehisa NEZU, Toshimitsu KOMATSU, Hirofumi OHNARI, \\ Masakazu OHASHI and Takashi ASAEDA
}

\section{1.はじめに}

近年においては，種々の乱流現象の中に存在する組織 構造が注目され，その特性についての数多くの研究がな されている. そして, 研究の重要性から工学・物理学・ 気象学・農学・医学などの広い分野で活発に研究が進め られている。しかしながら，この分野の研究の歴史は新 しいがために, 多くの研究は組織構造自体の研究にとど まっている. また, 水工学の現象の中で組織構造が果た す役割であるとか, 他の分野で得られている知見がどの 程度水工学現象亡関係があるのか, という観点からの総 合的な研究はまだ行われていない。このような現状認識 の下に，1985 年に水理委員会により若手研究者の研究 分科会のテーマとして, 本研究課題が取り上げられた. 本論文はその成果を報告するものである.

上述のように, 組織構造に関する研究の歴史はまだ浅 いので, 未確立の問題も多い. したがって, 従来の研究 の総括と並んで, この分科会での独自の新しい研究を進 展させ, その中から一段と進んだ見地からの水理学・流

*1 正会員 東京大学教授 工学部土木工学科 ( ₹113 文京区本郷 7-3-1)

*2 京都大学助教授 工学部 土木工学教室 ( ₹606 京都市左京区吉田本町)

*3 九州大学助教授 工学部 水工士木学科 ( ₹812 福岡市東区箱崎 6-10-1)

*4 徳山工業高等専門学校教授 土木建築工学科 ( (745 徳山市久米高城 3538)

*5 中央大学専任講師 理工学部 数学科 ( T112 文京区春日 1-13-27) *6 埼玉大学助教授 工学部 建設基礎工学科
( 1338 浦和市下大久保 255)

Keywords : coherent structures, open channel flows, inner layer, outer layer, longitudinal eddies, boil-kolk eddies, free shear layer, terminology
体力学的解明を目指した. 活動の目標としては, 水工学 に関する種々の組織構造に関する研究の有機的な関連, 組織構造と主流との関係，あるいは組織構造と乱流にお ける輸送現象との関係について現状を整理するととも に，今後の研究の方向を考えるうえでの指針を得ること とした.

河川乱流には多様な組織構造が存在している．河床の ごく近傍の内層には乱れエネルギーの発生機構である バースト現象が周期的に発生し，乱れを維持している. これは本研究における 2. の課題である. 一方，外層に はコルク・ボイル渦が存在し, 強い間欠性のある上昇流 が河床から水面に向かって発生し, 低運動量水塊の輸送 や土砂の巻き上げの原因となっている．これらのボイル 渦は河床形状と密接に関連しており, 次の 3 種類に大別 されよう. 第 1 種のボイルは砂漣や砂堆の背後に形成さ れるもので, 強いエネルギ一をもち, 土砂の垂直輸送の 主因となる、第 2 種のボイルは縦筋状の sand ribbon と の相互作用で発生するセル状の 2 次流（縦渦）に伴って 生ずるものであり, ridge 上に発生する上昇流が水面に まで達する．第 3 種のボイルは河床で発生した強いバー ストが合体を繰り返し，大規模な馬蹄型の渦となり，そ の先端が水面に達してボイルとなるものをいう.レイノ ルズ数が大きくなると第 3 種のボイルは弱くなるから, 河川でみられるボイルは第 1 種と第 2 種のボイルと考え られる. 本研究での課題では, 3. が第 2 種のボイルに, 4. と5. の主題は第 1 種のボイルに密接に関連したもの である。

本研究グループでは個々の課題の進展を図ると同時 に, 乱流における“組織構造とは何か”を全体討議のテ一 マとして議論を重ねてきた.その中で, 異なる研究グル一 
プの間で術語が異なっていたり，定義が異なっていたり して混乱がみられることが指摘された．統一した見解の 下に今後の研究の進展をさせるためにも, また, 現存す る問題点を討議するためにも共通の言語が必要であり, 術語の定義を充実させることが重要であることが痛感さ れた。したがって，全員の討議をもとに，術語の定義を 与える作業を行った。分科会活動を遂行した 4 年の間に 中間報告を土木学会水理講演会で行うとともに，これら の研究課題に関心がある多くの研究者の参加を求めて本 研究班が独自に開催したオープン・シンポジュウム（於 中央大学，1987 年 9 月）で総合的な討議を重ね, それ らの内容が本研究報告に反映されている. 本報告の付録 に揭げた定義および解説は，本分科会以外の研究者達の 多くの提言をも十分に検討し，これを反映させるととも に，研究グループ構成員の全員の了解を得るまで討議を した結果であり，現時点での統一見解としてまとめられ ているものである.

\section{2. 開水路乱流における内層の組織構造}

組織構造を認識する方法としては, 点計測法, 可視化 法, 数值計算法がある. 点計測法では条件付き検出が行 われ，最適な検出基準を決める努力がなされている. 可 視化法では三次元的可視化法への努力がなされ，2 断面 同時可視化，連続断層面可視化などが試みられている.

また，可視化法と流速計測の同時併用の重要性が認識 されるようになっているといえよう. 数值解析法は, 最 近スーパー・コンピューターを CPU 時間のみで 10 日 間以上も駆使して Navier-Stokes 方程式を直接解き, チャネル流れの壁乱流で発生する組織構造を定量的にも かなり再現できる段階にまで達した ${ }^{14)}$. そして, 開水路 乱流や乱流境界層における組織構造の解明にも, このよ うな乱流の直接数値計算法 [Direct Numerical Simulation (DNS) という] は今後ますます発展するであろう ことが期待されている。 それぞれの手法の展開は固有の 重要性をもっているが, 組織構造のように認識法自体が 確立途上にある現象に対しては, 異なる手法を総合的に 用いることが最も重要である15).

最近の研究 ${ }^{16)}$ による, 三次元計測結果と直接数值計 算法の結果が良い一致を示すことが報告されており，今 後実験結果と数值計算との比較研究が期待される.

粘性底層には, 低速之高速の領域が横方向 $(z$ 軸方向) に交互に並ぶ，いわゆる streak 構造が存在する. 低速 縞 (low speed streak) の平均間隔 $\lambda_{z}$ は

$$
\lambda_{z} U_{*} / \nu \simeq 100
$$

であることが明らかにされている177,18)。低速縞の主流方 向 $\left(x\right.$ 軸方向）の大きさ $\lambda_{x}$ は

$$
\lambda_{x} U_{*} / \nu \simeq 1000
$$

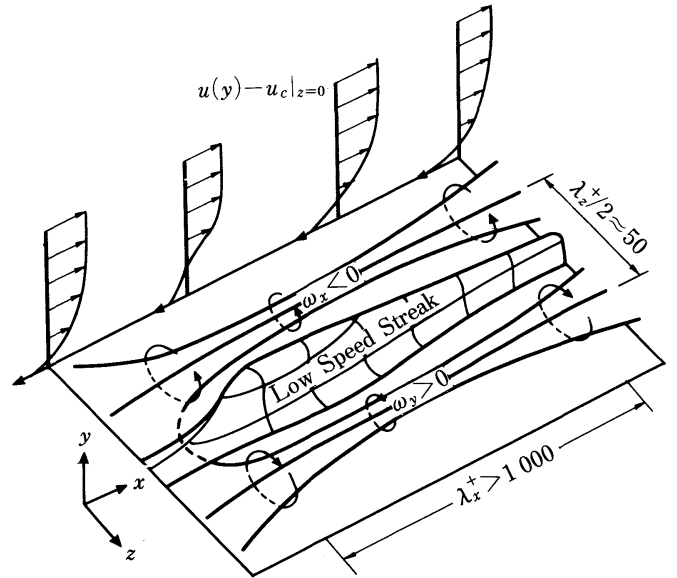

(a)

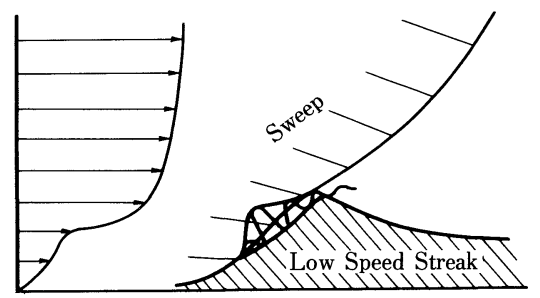

(b)

図一1 Blackwelder らの縦渦と低速縞モデル

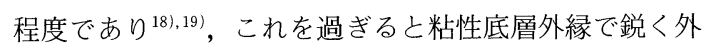
側に ( $y$ 軸方向に) 浮上する streak lift-up とよばれる 不安定な運動を示す。そして, 浮上した低速縞は激しく 三次元的に摇動 (oscillation) し,さらに break up して, 細かなスケールの混沌とした運動, すなわちカオス的運 動へと移行する．この 3 つの連続した過程がまとめて burst（バースト）現象とよばれ，それは内層（厚さ $y^{+}$ <100）の中で生ずる.

バーストの平均周期 $T_{B}$ は，レイノルズ数およびフ ルード数に無関係に外部変数で統一的に支配され, 開水 路流れでは

$T_{B} U_{\max } / h=1.5 \sim 3.0$

である ${ }^{20)} . U_{\max }$ は最大流速， $h$ は水深である．境界層 と管路流れでは

$$
T_{B} U_{\infty} / \delta=3 \sim 8
$$

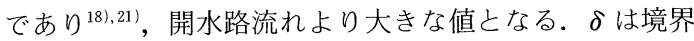
層厚さ， $U_{\infty}$ は境界層外縁での流速であり，管路流れで は $\delta$ が半径 $R$ となる. しかし最近, Blackwelder ら 22 やWillmarth ら ${ }^{23}$ は境界層流れをより高精度に計測して $T_{B}$ の内部変数依存仮説を提唱し,

$$
T_{B} U_{*}^{2} / \nu \simeq 250
$$

であるとし，上述の従来の定説になっていた $T_{B}$ の外部 
変数依存性に疑問を示した。この本質的に重要な疑問を 解決するために, ごく最近, Luchik ら ${ }^{15)}$ は管路流れの $T_{B}$ を詳細に検討し, 内部変数依存性の方が外部変数依

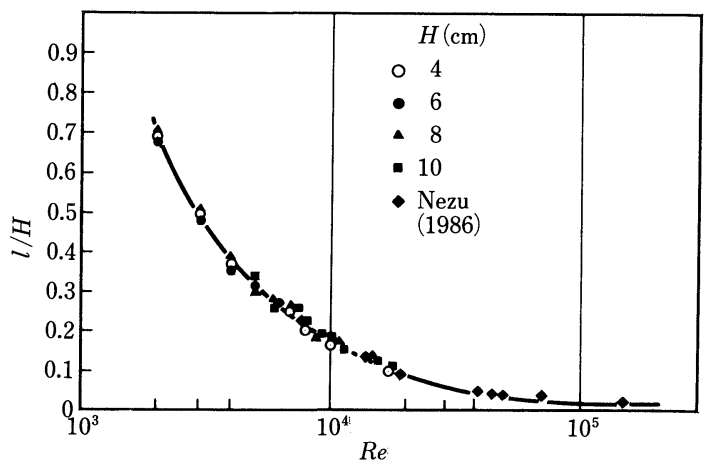

図一2 内層水深比とレイノルズ数の相互関係

\begin{tabular}{r|r|r|r}
\hline & \multicolumn{1}{|c|}{$\lambda^{+}$} & \multicolumn{1}{c|}{$b^{+}$} & \multicolumn{1}{c}{$l^{+}$} \\
\hline$x$ & 1000 & 167 & 172 \\
\hline$y$ & 7 & 12 & 20 \\
\hline$z$ & 10 & 15 & 21 \\
\hline
\end{tabular}

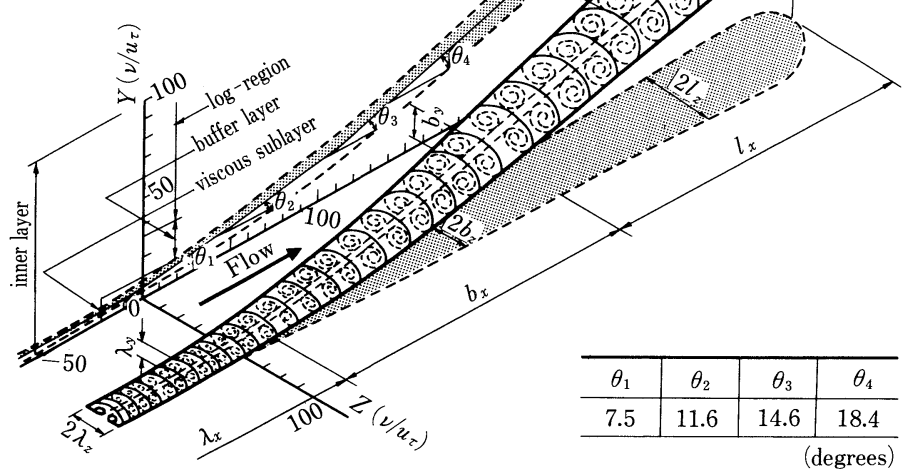

(a) 平均スケールモデル

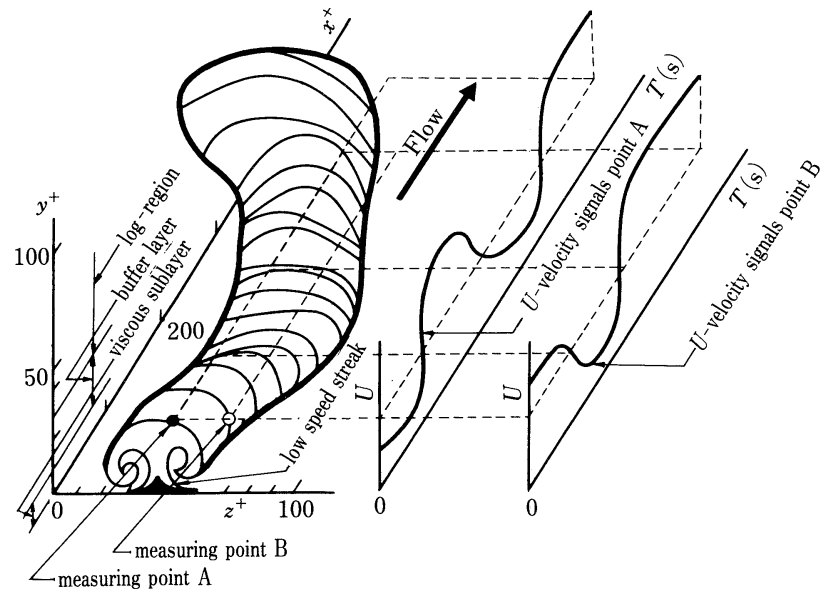

（b） 流速変動対応モデル

図一3 壁縦渦の概念モデル
存性より可能性が高いことを見出したが，実験で用いた レイノルズ数の範囲が狭いために，まだ明確な結論を得 るまでには達していない。

バースト運動の時間的な特性は, (1)ejection-sweepejection という周期的な過程を示し，(2)ejection および sweep により瞬間レイノルズ応力が発生し，乱れが生成 される. 空間構造の特徵は, (1)主流方向の速度変動 $u$ の空間スケールは，鉛直方向の速度変動 $v$ のスケール より大きい，(2)sweep の空間スケールは ejection のス ケールより大きい，(3)バーストの影響域は内層外縁まで は増加するが，外層に入ると減衰する，(4)ejection の空 間的広がりは下流側に大きく, sweep は上流側に大きい. このためオイラー的な計測では, ejection から sweep への移行が急激に生ずる，(5)バーストは平均渦径程度の 大きさの渦構造をもち，凍結乱流的に移流される ${ }^{43)}$.

バースト運動の時間・空間特性を表現 するモデルとして，馬蹄型渦，ヘアピン 渦など数種類の渦のモデルが提案されて いる.

本研究における成果は次のようにまと められる。

図一2に示されるように，一定勾配下 の開水路乱流における内層水深比は第一 義的にレイノルズ数によって決定され る. 組織構造を対象とする研究において は，まず流れ場の内外層比を把握するこ とが重要である，この図より，レイノル ズ数が増加すると, 内層厚さは水深に比 べて非常に小さくなり外層の占める領域 が大部分となる。この流れ場では，バー ス卜同士が合体して群体化 (agglemeration という) する可能性がつい最近指 摘されているが24)，まだ実体は不明のま まである，今後河川などのより高いレイ ノルズ数での流れのバーストの挙動を解 明することが必要であろう。

開水路乱流内層には互いに反対方向に 回転する渦対を有する “壁縦渦”が多数 形成される，この壁縦渦は，中央部から 先端部にかけては従来のへアピン渦ある いは馬蹄型渦 ${ }^{55}$ 之同一であるが，その下 部においては類似性が認められない。図 一-3(a)に示されるように粘性底層, バッ ファ一層, 内層対数領域における壁縦渦 のスケールと流れ方向への傾斜角が明ら かにされた25).

内層の横断面視とレーザー流速計によ 

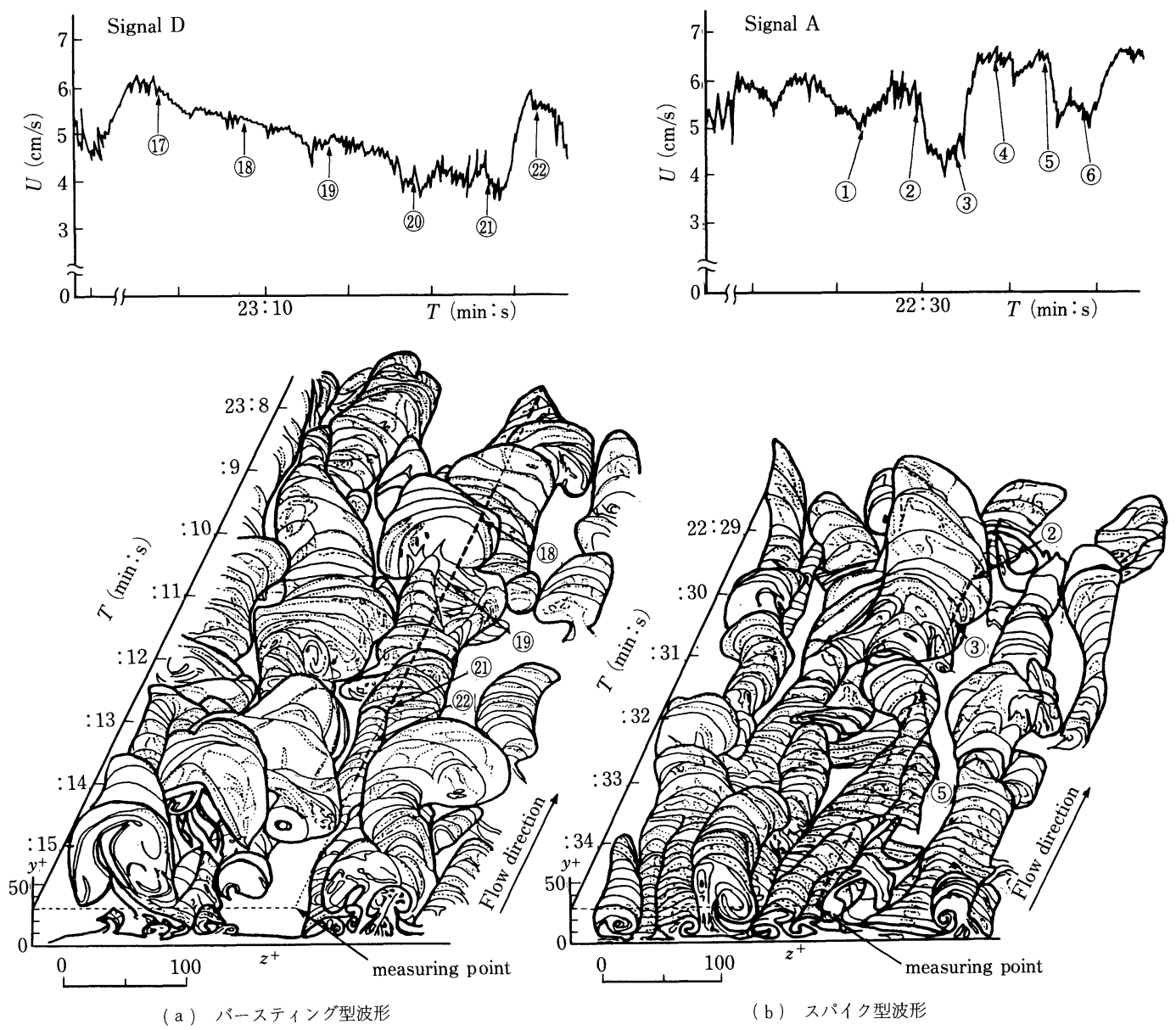

図一4壁縦渦の時空間構造と同時計測波形

る流速計測の同時併用により, 流速変動と壁縦渦との相 互関係が明らかにされた ${ }^{26)}$. 渦対間の上昇流部が計測点 を通過する際には流れ方向流速が減少し，渦対による下 降流部が計測点を通過するか, 壁縦渦がまったく離れて しまうと流れ方向に高速域が出現する. 図一4に示され るように，流速信号の波形の特徴としては，バースティ ング型とスパイク型の 2 種に分類できる. 前者は数個の 壁縦渦が集中して形成された領域が計測点を通過すると きに現われ, 後者は壁縦渦が比較的短周期で摇動するこ とによって出現し, この形成頻度はバースティング波形 をはるかに上回ることが観測された. また，この計測に 基づいて壁縦渦の概念モデルが提案され (図一3(b)), VITA 法 ${ }^{27)}$ における最適なパラメーターとして移動平均 時間の内部無次元值は $T^{+}=U_{*}^{2} T / \nu=13$ および, しき い值 $k=0.8$ が得られた ${ }^{26)}$ (図一5).ここに $T$ は移動平 均時間である。

また, 流れ方向への移動横断面可視化により, 壁縦渦 のラグランジュ的追跡が行われた. 壁縦渦の横断面形状
は短期的には微小な変化を遂げてゆくが，その基本骨格 は平均的に $T^{+}=92$ の間は保持されることが明らかと なった.この間は, テイラーの凍結乱流の仮定が近似的 に成立するものと推測された.

壁縦渦の三次元鳥瞰図や側面図を, Kim ら ${ }^{14)}$ による数 值解の ‘vortical structure’ と比較すると, 定性的には両 者はほぼ類似しており, 今後は定量的な比較が必要と考 えられる。

\section{3. 開水路乱流における外層の縦渦構造}

河川の流れは, 乱れが水面まで達した自由表面をもつ 流れであり, 水面に縦筋やボイル等の組織化された大規 模乱れの兆候が現われており, 一般には土砂を浮遊・掃 流している流れで, 境界が複雑な地形の影響を受けてい る多様な流れである。これら河川乱流には多様な組織構 造が存在しており, 水流の抵抗, 流砂量, 物質の拡散お よび輸送, 水質因子の分布などに重要な役割を占めてい ると考えられる. 

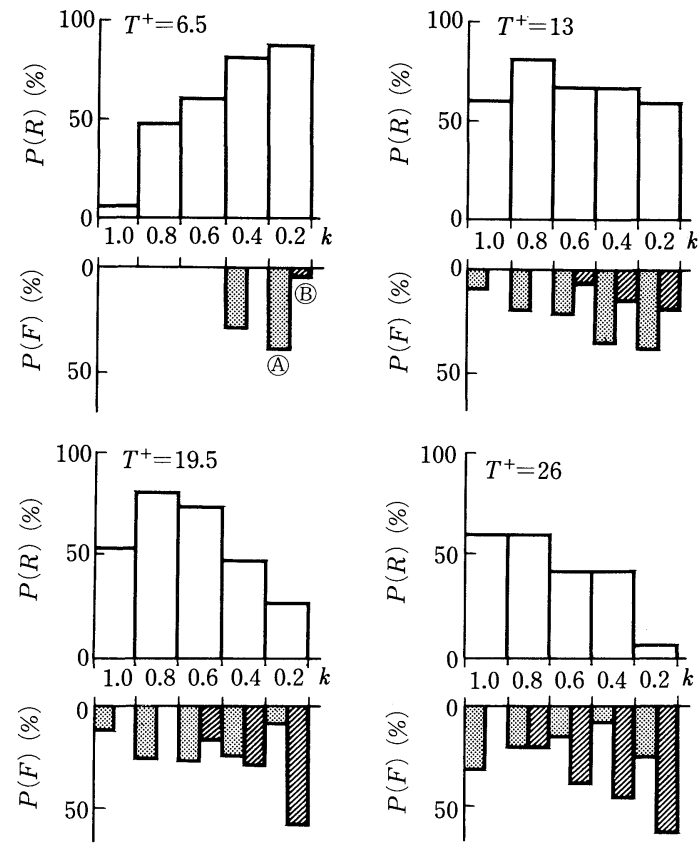

図一5 壁縦渦と同時計測の VITA 法検出波形の対応可非分布 $(P(R)$ は対応, $P(F)$ は非対応のそれぞれの頻度分布 $)$

ここでは, 内層の壁縦渦, バースト, あるいはボイル 渦との関連が最も深いと思われる, 開水路流れの外層に おける縱渦について研究を行った.

外層における縦渦については洪水時の河川水面の泡の 分布 ${ }^{28}$ および移動床砂面上の縦筋 ${ }^{29}$, あるいは表面流速 分布を立体写真計測法により解析した結果が報告されて いる ${ }^{30}$. 木下 ${ }^{30)}$ は, 固定床開水路の系統的な測定から, 底面が粗面のときは, 表面流速分布には縦筋の低速列か ら低速列までの間隔がほぼ水深の 2 倍で現われること, また底面が滑面の場合は縦筋の空間的位置は，常に横方 向にゆらぎ不安定であることを示した。また，底面上に うろこ状砂州を模式化した形状のウロコ床や斜め格子状 の細かい溝を掘り込んだ開水路上の流れの中に生じる安 定度の高い縦渦について表面流速の詳細な研究を行っ た。

一方, 水流内部の乱れの研究は, 可視化法により水流 の乱れを光学的に記録する方法，流速計により乱流計測 を行う方法により数多くの研究が行わ机ている．底面上 に人工縦栈粗度を設けた開水路の乱流計測により流速分 布に対数則を適用し摩擦速度を求め, 縱渦の下降流部の 摩擦速度が上昇流部に比べて大きくなることがわかって いる311. また, 縦渦の壁面せん断応力への影響について の研究 ${ }^{32}$ により縦筋河床の形成領域と掃流力の分布特性 が明らかになり，掃流力の分布に縦渦や乱れによる横断 方向の輸送が重要な役割を果たしていることがわかって

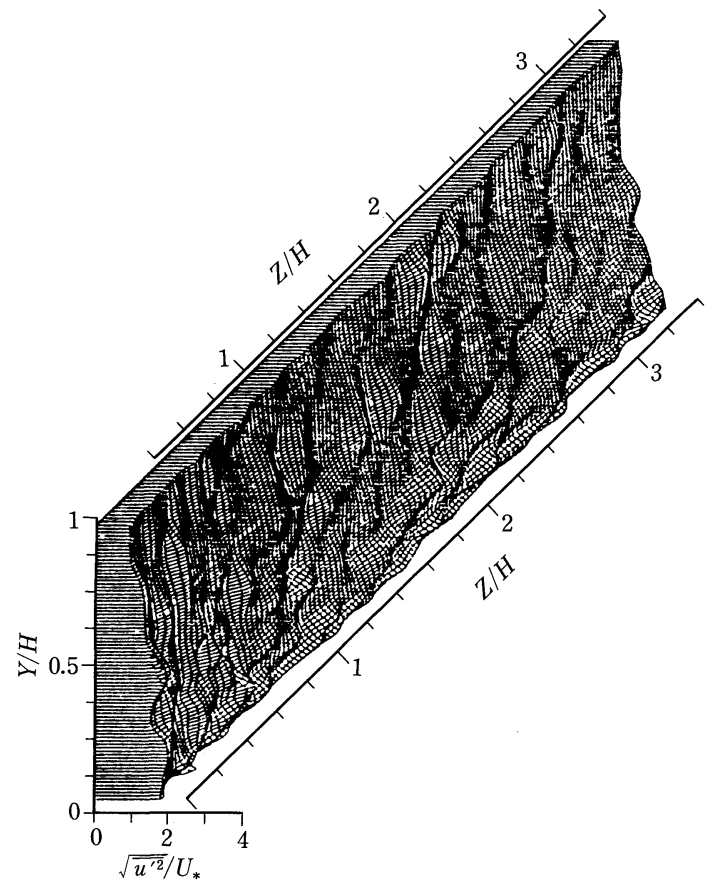

図一6 $\boldsymbol{u}^{\prime}$ の乱れ強度横断分布図

いる.

しかしながら, 従来の研究では開水路中での縦渦の乱 流計測を精度よく行うためにはウ口コ床や斜め格子溝, あるいは栈等の人工的にらせん流を形成させる要素を与 えなければならなかった．境界層の流れにおけるバース 卜現象等組織構造の解明は滑面状態に対して最も進んで おり，外層の縦渦と内層の構造との関連を論ずるには滑 面を対象とするのが望ましいと考えられてきた。本研究 では，人工的にらせん流を形成する要素を与えずに，一 様な平坦床開水路流れでも，水路幅・水深比が適当な条 件を満たすときには安定な縦渦が存在することを確かめ $た^{33), 34)}$. 高速域つまり縦渦の下降流部では乱れが小さく, 低速域つまり上昇流部では乱れが大きいといった傾向が みられた (図一6). また，2本のホットフィルムプロー ブによる同時計測より時空間相互相関係数（図一7）を 計算し，図より横断方向の縦渦の波長が水深スケールに 成長しているのが認められる. 2 点における, レイノル ズ応力の值がその 2 点においてともに上昇流またはとも に下降流によって生起される確率の横断方向の分布を求 めレイノルズ応力の発生に寄与する二点同時生起確率が 水底および水面近くを除いては水深程度の横方向間隔で 山が連なっているのが示される(図一8).

縦渦のようにらせん運動を伴う流れにおいては，速度 ベクトルの変動が時間的に回転していると考えられるた め，速度ベクトルの時系列をそのまま取り扱うことので 


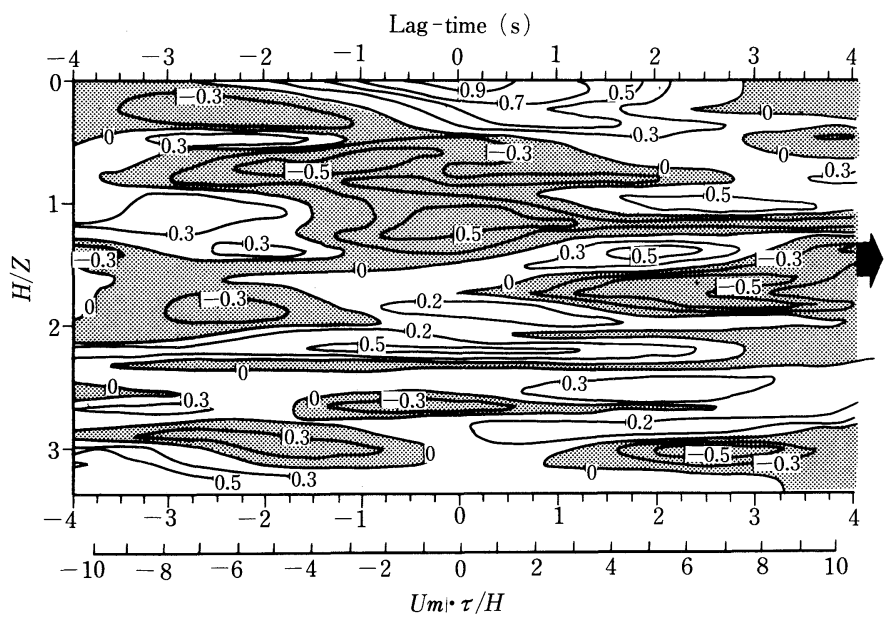

図一7 R $\tilde{\boldsymbol{u}}_{F} \tilde{\boldsymbol{u}}$ の等值線図 $(y / H=0.23)$

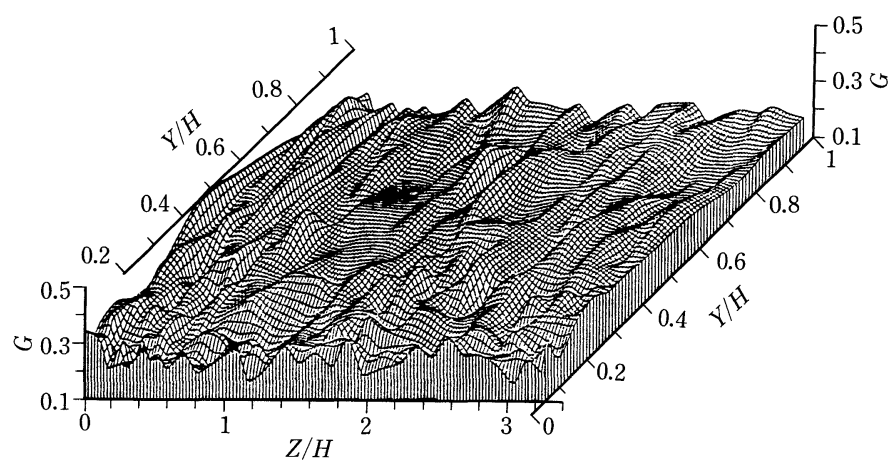

\section{図一8 レイノルズ応力の発生に寄与する上昇流または下降流の} 二点同時生起確率の横断分布図

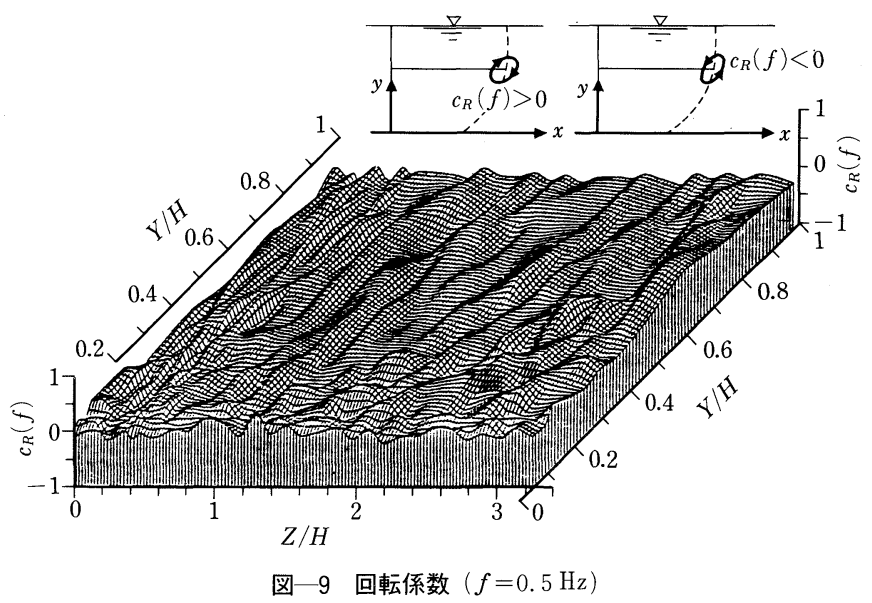

きる回転スペクトルを，2方向の流速成分より計算した (図一9). その結果, 発生した乱れの低周波成分の上方 への伝播の状況が，スペクトル形状の変化より明らかと なった。 また, 各測点における渦の回転特性より, 低速
域が乱れの発生・発達に重要な役割を果たしていること が明らかとなった。一方, 高速域では, 底面付近での乱 れ生成は, 低速域と同様と考えられるが, 縦渦がつくる 下降流により上方への乱れ伝播が抑制され乱れの減衰が 
著しいと考えられる.

内層内の壁縦渦は底面の影響を強く受けるのに対して 外層の縦渦は自由水面と低面および側壁の境界の影響を 受ける.また，外層の縦渦は内層の壁縦渦に比べてかな り安定している. Paulley, Eaton ${ }^{35)}$ は, 2つの HalfDelta Wing により人工的に縦渦対を発生させ，逆回転 する縦渦対は渦核の距離が近づくにつれ渦度の極大值は 低下し，渦が成長し，境界との相互作用が強いことを示 した. 今後, 内層内の組織構造と外層の縦渦との関係, 渦の安定性の解析, 境界の影響等についての詳細な解明 が待たれる.

\section{4. 開水路段落ち剝離流の組織渦}

段落ちは河床形状の不連続を示す最も簡単で，かつ典 型的な例であり，これにより発生するコルク・ボイル渦 の発生機構や動特性を解明するために行われた。

段落ち流れに形成される組織渦には, (1)段落ち頂部か らの剝離渦之, (2)再付着点から放出されるコルク・ボイ ル渦の 2 種類がある. 剝離渦は, 段落ち頂部から発達す る強いせん断層のため Kelvin-Helmholtz の不安定性に よって剝離した流れの変動が線形増幅し, やがて rollup して組織渦が形成される. 混合層に共通した組織渦
であり, 渦の合体により渦径が増大してゆく. 再付着点 からのコルク・ボイル渦の発生機構には不明な点が多 く, 本研究の中心はレーザー流速計と圧力変換器を用い た時空間相関解析を行うことにより，この発生機構を究 明することにある。

時間平均された再付着点長さは, レイノルズ数のみな らずフルード数にも依存することが明らかにされた。再 付着点は時間平均された再付着点のまわりに変動してい る.この特性を定量的に評価するため, 全計測時間内で 逆流の生ずる時間割合 $I_{r}$ が用いられた. $I_{r}=0.5$ は時間 平均された再付着点位置とよく一致する. また， $I_{r}$ が 0.1 から 0.9 まで変化すると, 瞬時の再付着点位置は段 落ち高さの 3 7 倍の範囲を変動し, 剝離泡の伸縮が生 ずる。この伸縮運動により, 何らかの組織渦が再付着点 から放出されることが示唆された ${ }^{36)}$.

壁面で計測された圧力スペクトルには組織渦の存在を 示すピーク部が現われ，最もエネルギーの大きい第 1 ピークの周波数は, 剝離泡の中央部で最大, 再付着点で 最小值を示す. ステップと同一高さで乱れ強度は最大に なり，この位置に沿う速度スペクトルのピーク卓越周波 数は, 圧力変動と同じく再付着点付近で最小となる. 圧 力と速度の卓越周波数（低周波変動）はほぼ同一で, 前

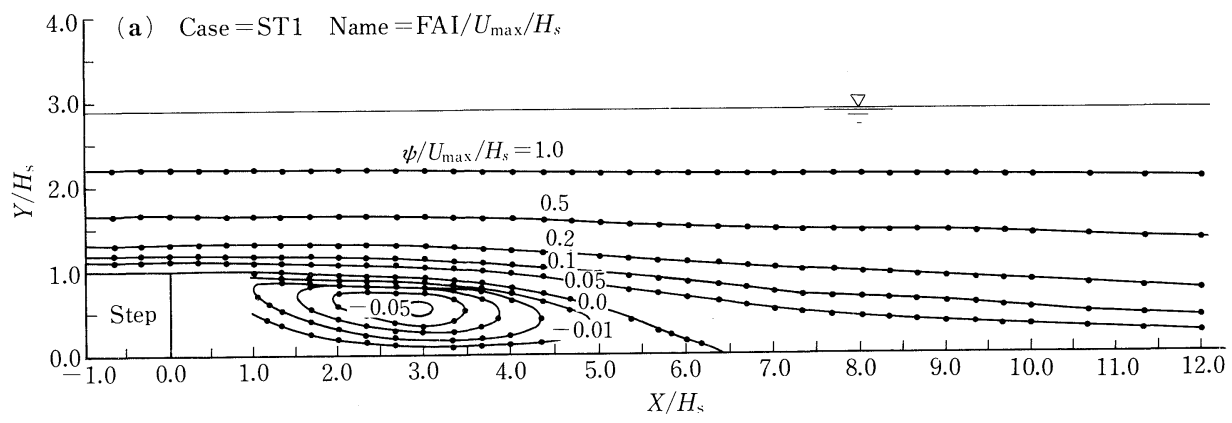

(b) Case $=\mathrm{ST} 3 \quad$ Name $=\mathrm{FAI} / U_{\max } / H_{s}$

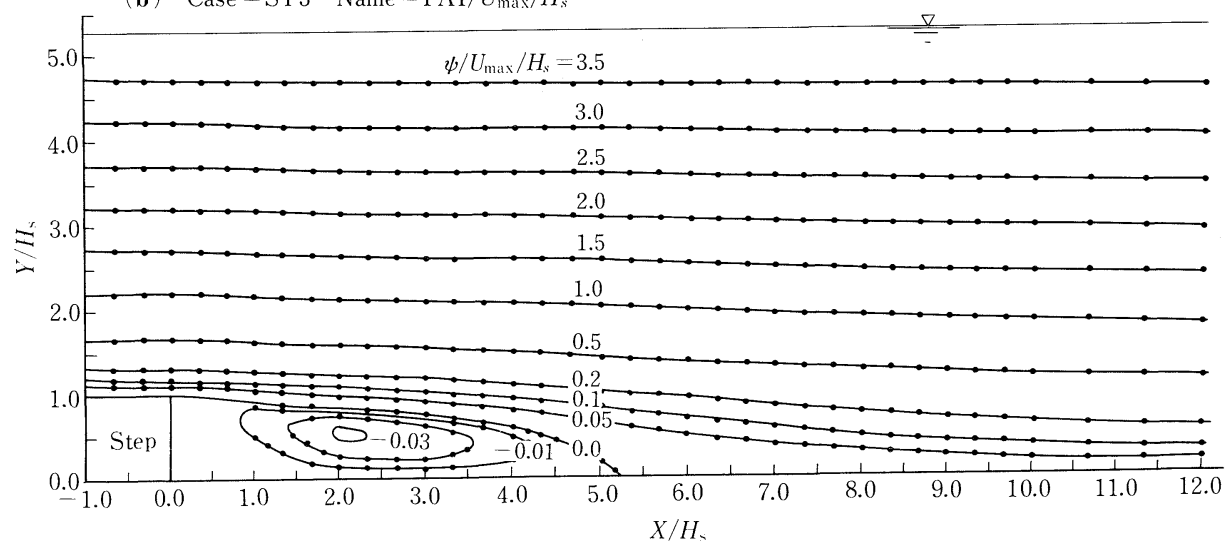

図-10 段落ち流れの流線 


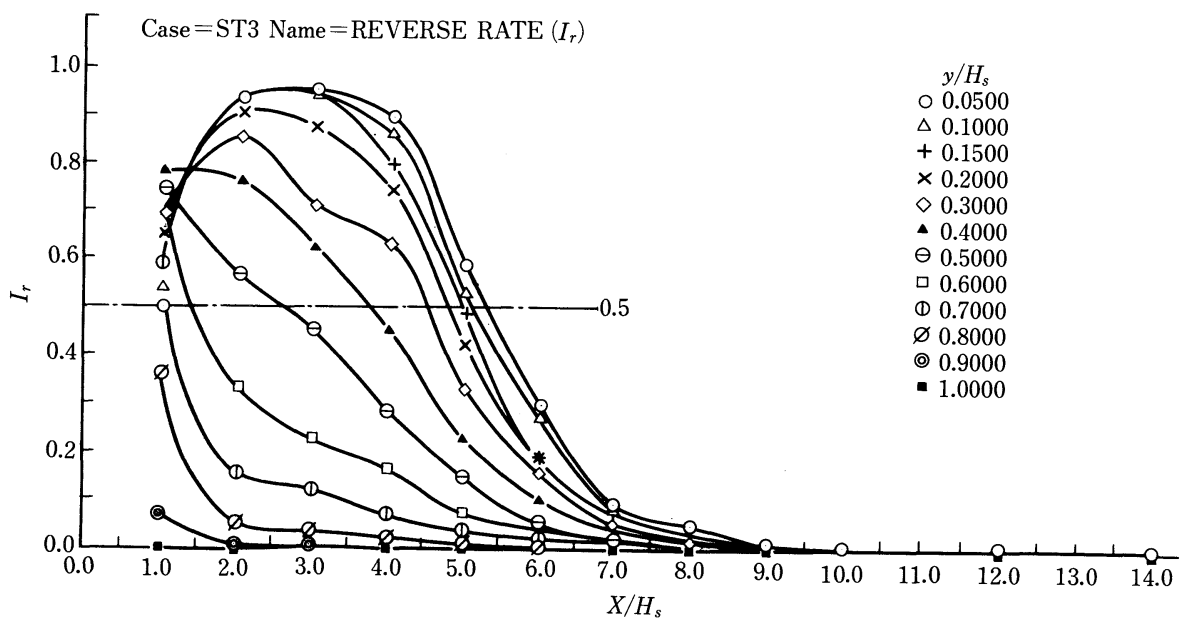

図一11 逆流率の変化

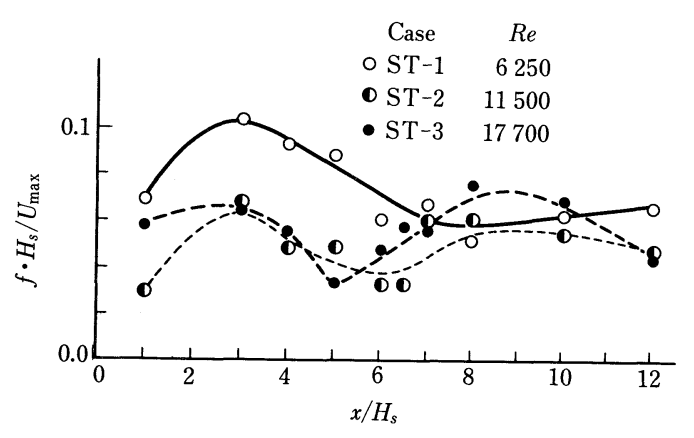

図一12 壁面圧力変動の卓越周期

縁剝離流あるいは河川で観測されたボイルの発生周期の 無次元数とほぼ同じ位置を示した ${ }^{36)}$.

再付着点に設置された圧力センサと主流方向および鉛 直方向の速度変動との時空間相関からは次のようなこと がわかった、コルク・ボイル渦が浮上すると, 壁面圧力 は負となり, また低運動量となる相関が強い. 自由水面 付近で圧力-速度の相関が高い領域が周期的に現われ, この周期は前述の低周波変動とほぼ同一であり, 移流速 度は局所平均流速に比べてかなり低いことが判明した。

また, 1 台のレーザー流速計を再付着点に固定し, も う 1 台のレーザー流速計を移動させ, 速度の時空間相関 を解析した。高相関領域では乱れの主流成分と鉛直成分 の相関は負であり, 低運動量の渦塊が浮上することがわ かった ${ }^{36)}$.

剥離渦とコルク・ボイル渦の間の干渉は, 可視化観測 により次のような実体が明らかとなった，剝離瀜は高周 波で変動しているが, 剝離渦が再付着点に到着すると再 付着点の低周波変動を刺激して大規模なコルク・ボイル 渦を放出する．剝離渦が到達すれば必ずコルク渦が放出 されるわけではないが, コルク・ボイル渦が発生すると

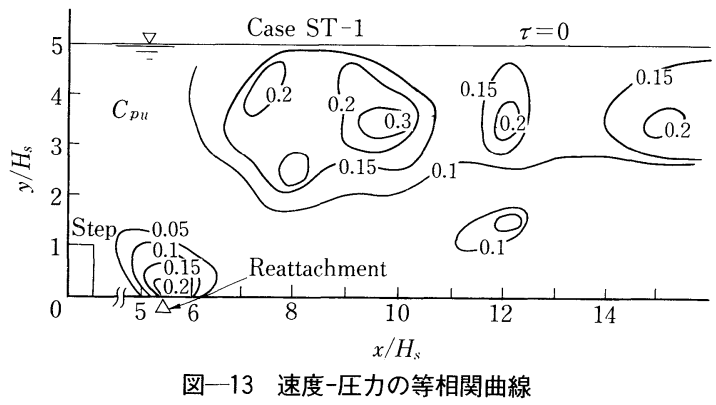

きには必ず剝離渦が引金になっていることが示され $た^{36}$. 再付着点付近での剝離渦と剝離泡全体の変動との 相互作用や位相関係は三次元的な複雑さをもつもの之考 えられ ${ }^{37), 38)}$, これらの詳細な解明が今後の課題である.

本研究で対象としたコルク・ボイル渦は, 付録に示す ようにいわゆる「第一種のボイル」であり, 自由水面を 有する流れ, すなわち河川で現われる組織渦の中でも最 も強い乱流渦塊に属す. 河川で観測される強いボイルに は高濃度の浮遊砂を伴うことがよく指摘されてお $り^{39), 28)}$, 浮遊砂の浮上・輸送機構を解明するにはこれに 寄与するボイルの役割を知ることが不可欠であり, 水 理・水工学上き水めて重要な課題である.このような河 床波背後に生ずるボイルとこれに伴う浮遊砂との関係を 定量的に解明するために, 再付着点に設置したレーザー 流速計による流速変動とその下流に設置した浮遊砂濃度 計による濃度変動との時空間相関構造が計測された ${ }^{40)}$. その結果, 低運動量の渦塊が浮上する, すなわちボイル が発生すると, きわめて高濃度の土砂が浮上し, 流れに よって輸送されることが実証された.今後の研究として, 浮遊砂の三次元濃度分布に及ぼすボイルの三次元構造性 や, 増水期之減水期とで河床波背後の土砂浮上現象が異 なることから，このような剝離渦と浮遊砂に及ぼす流れ 


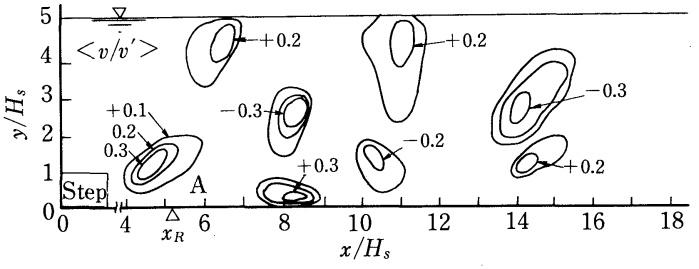

(a) $\tau=-0.2 \mathrm{~s}$

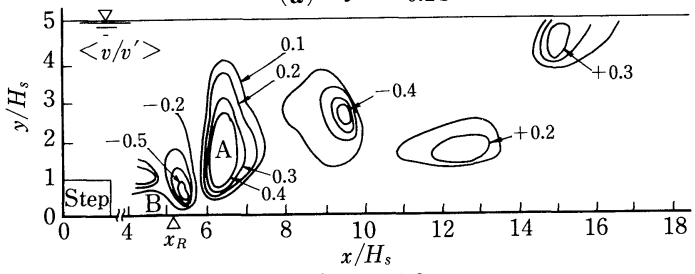

(b) $\tau=0.0 \mathrm{~s}$

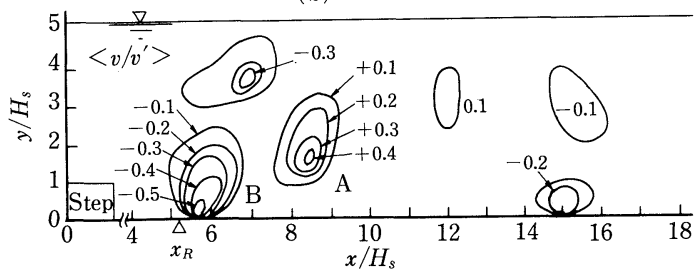

(c) $\tau=0.2 \mathrm{~s}$

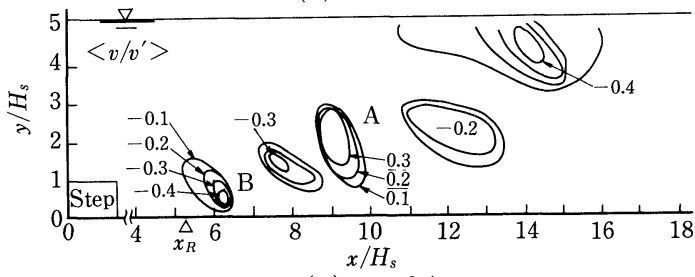

(d) $\tau=0.4 \mathrm{~s}$

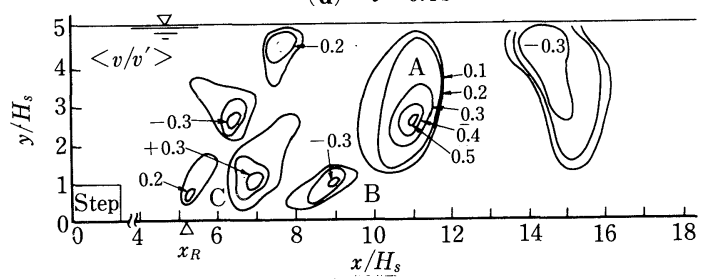

(e) $\tau=0.6 \mathrm{~s}$

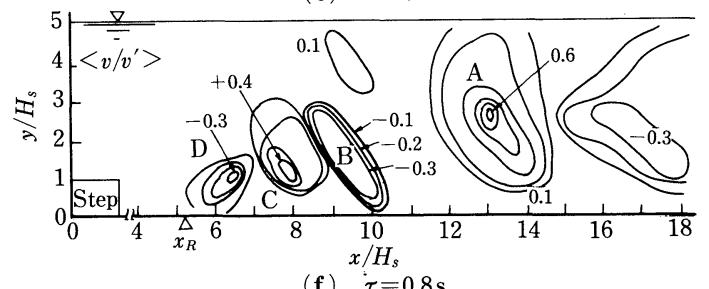

(f) $\tau=0.8 \mathrm{~s}$

図一14 $p(t)>p^{\prime}$ での条件付き平均パターン $\left\langle v / v^{\prime}\right\rangle$

の非定常性を明らかにすることが必要である.

\section{5. 地形変化によって河道内に生ずる組織構造 とその効果}

河床がさまざまに変化する場での流れは非常に複雑で

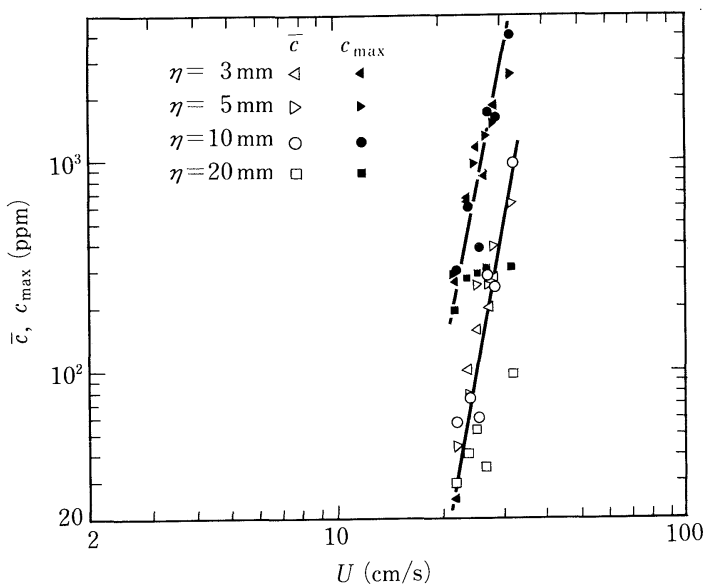

図-15 三次元的な砂漣上の浮遊砂濃度と平均流速の関係

あり，その実体を把握するのは多くの困難を伴うが，こ うした流れは河道の形式，また河川をめぐるさまざまな 現象において非常に重要な働きをしている. その中で, 特に, 流砂, ひいては河床形状の変化に及ぼす効果は大 きく,これまでにもさまざまな現象が報告されている. このような現象の多くは, 地形の変化から生ずる複雑で 組織的な構造 [乱流分野では“複雑流れ (complex flow)” という] ${ }^{12), 13)}$ に起因していることが多く, その特性を調 ベること, さらには流砂との関連を調べることは重要な 課題であるといえる.

Ikeda・Asaeda $a^{41)}$ は，砂漣近傍での砂の巻き上がりを 調べ局所的な流速変動が流砂量に非常に大きな影響を及 ぼすことを示している. 実際の河川内の地形は非常に複 雑であり，こうした地形の複雑性からもより強い局所的 な流れを生じており，このような流れが浮遊砂の動特性 に及ぼす影響はきわめて大きいと考えられる.一方, 河 川内には次に示すような複雑な地形が存在しており,こ れに伴った次のような局所的な流れが存在している.

複断面水路においては，流れ方向に列をなす水面渦が きわめて明瞭に観察される。この水面渦の波数は低水路 と高水敷上の流速の差から生ずるせん断層の不安定な領 域に入っており，実際には上昇流は広い場に平均して存 在するのではなく, 1 つの組織構造である渦に集中して 存在している ${ }^{42)}$.この上昇流は, 低水路と高水敷のジョ イント隅角部から，乱れの非等方性のために励起された 渦度の集中した組織渦（低運動量をもつ）が低水路側の 水面へと間欠的に輸送された結果であり，このジョイン 卜部から低水路水面へと斜めに上昇するため，「斜昇流」 とよばれる ${ }^{43,44)}$.

この流れによる揚力のために，高水敷縁部の剝脱を招 き, また, 低水路内の高濃度の浮遊砂を高水敷側に輸送 する役割を担う。その結果として高水敷縁部に多量の砂 


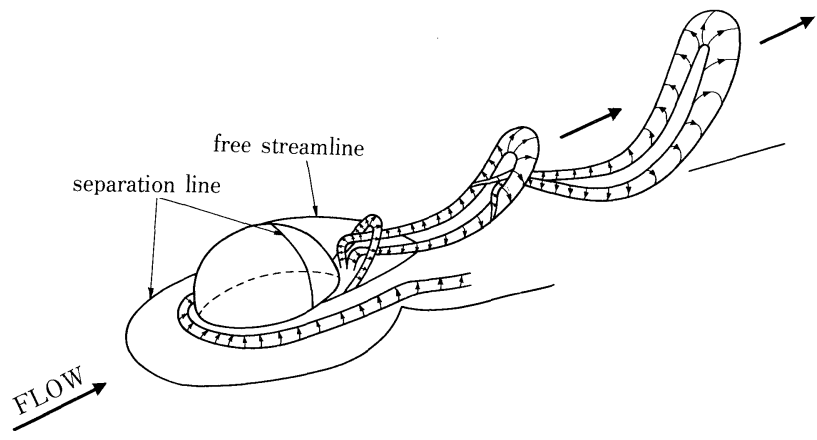

図一16 剝離渦のモデル

が堆積し，河川全体の流通能力を大きく減少させる. ま た，こうした現象，特に高水敷の破壊においては，平均 的な力よりも瞬間瞬間の力の方が問題になるため，単な る平均量としての扱いではなく, 組織渦による効果を考 慮することは必要不可欠である。

湾曲部においては, 遠心力による二次流が発生するこ とはよく知られた現象である。この現象も 1 つの組織構 造といえるが，その発生機構・規模において他のものと 多少異なるので，ここでは触れないことにする.

ハンプ，たとえば半円球の障害物，に沿ったせん断流 の効果によって渦が形成され, 後流部で剝離して馬蹄型 の渦となる.こうした渦の発生周期は, 一般にストロー ハル数 $S_{t}$ で整理される. $S_{t}$ の值がある值より大きくな ると, いくつもの組織渦が, ハンプ直後の後流域で合体 して放出されるようになり，発生周波数が増加するにも かかわらず, 後流域後方への渦の放出周波数は小さな值 に保たれる ${ }^{45)}$. なお，最近，Acarlar · Smith ${ }^{46)}$ は，層流 境界層内に半円球を設置し，ここから発生する非常に規 則的な馬蹄型渦を水素気泡法で詳細に追跡・解析し, 乱 流境界層のバーストのモデルである馬蹄型渦と酷似する

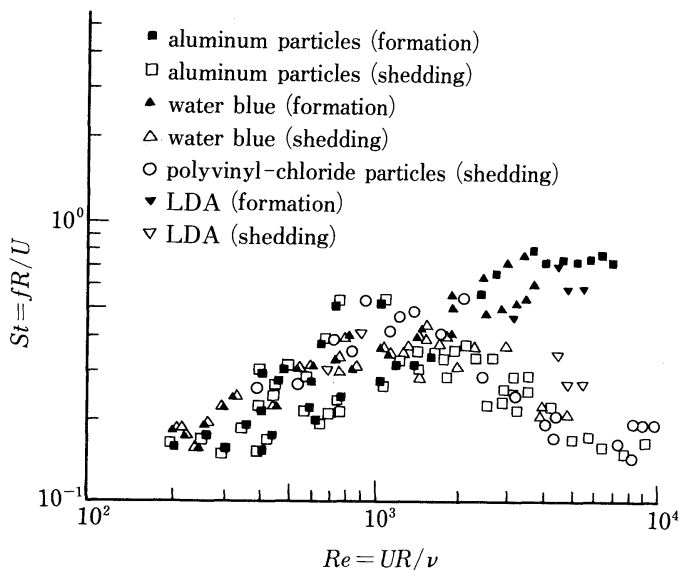

図-17 Re と $S_{\iota}$ の関係
ことを明らかにしている。

河床勾配が徐々に増大するような水深変化部に渦が存 在すると，一定勾配水路と比較してより強い上昇流が生 ずる可能性が示されている(77),48)。

\section{6. 混合層における組織渦}

従来の研究により組織渦は乱れやレイノルズ応力の発 生に寄与することが明らかとなっているが，特に噴流や 後流また混合層などの自由乱流においては組織渦は混 合・希釈や連行現象にも大きく関与している。したがっ てその特性を定量的に明らかにすることができれば組織 渦の制御や応用が可能となり, 河川の合流部の混合やプ ルーム・噴流を用いた拡散・希釈などに関して組織渦の より積極的な工学的利用に道が拓けるものと思われる.

ここでは自由乱流の中では流況が比較的単純で計測が 容易なせん断混合層において, 組織渦の時空間特性や組 織渦と連行による物質輸送を中心に解析を行った ${ }^{49)-52)}$.

従来より“混合層流れでは組織渦は合体を繰り返しな がら流下し，そのスケールと周期を増大させていく（プ ロセスーI )”ことが報告されているが，今回の可視化実 験から“混合層厚程度のスケールをもって発生した組織 渦は強い平均せん断流によってすぐに引き延ばされて, 組織渦の下部は取り残され上部は引きちぎられるように して流下する. 取り残された下部は後発の渦の上部と, また渦の上部は先行した渦の取り残された下部と新たに 組織渦を生成するか, もしくはその上を素通りして流下 する.したがって組織渦の生成・崩壊は局所的で，1つ の組織渦の寿命時間は短い（プロセス-II )” (写真一1) ことが新たに確認された. 混合層の組織渦像としてはレ イノルズ数が小さいときはプロセス-Iが，レイノルズ 数が大きくなるとプロセス-II が卓越する傾向がある.

せん断混合層の組織渦の周期は, 平均流速の最大勾配 に反比例して, $T(d u / d y)_{m}=6.64$ となり, 平均流に直 接規定されていることがわかった（図一18）。組織渦の 時空間相関特性を 2 本のホット・フィルム流速計で実測 


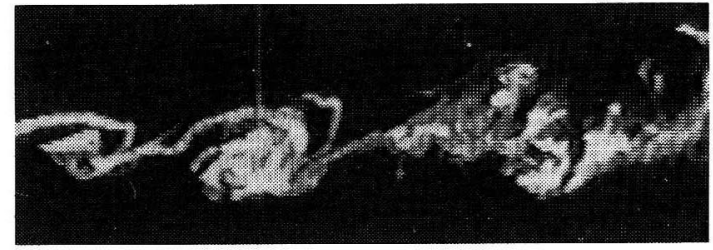

$t=t_{0}$

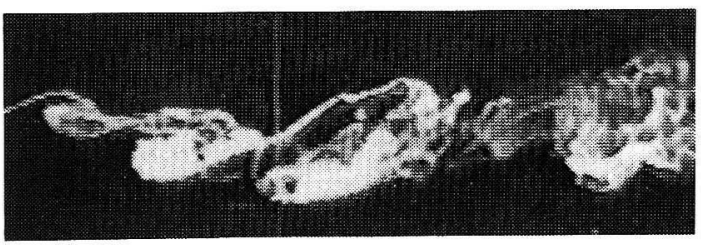

$t=t_{0}+0.4(\mathrm{~s})$

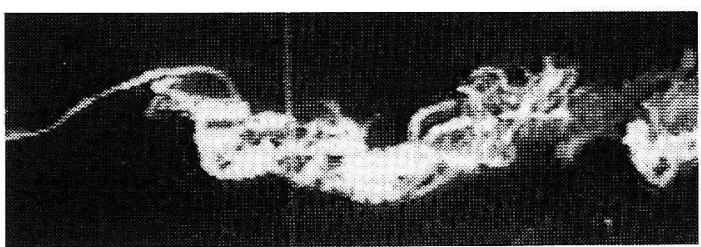

$t=t_{0}+0.7(\mathrm{~s})$

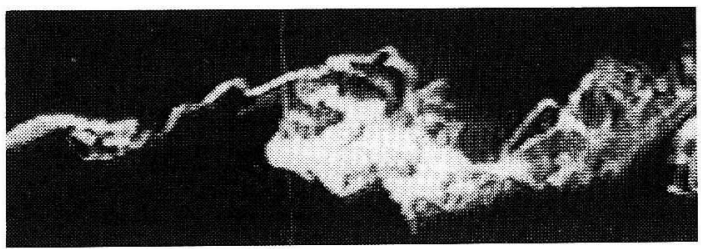

$t=t_{0}+1,1(\mathrm{~s})$

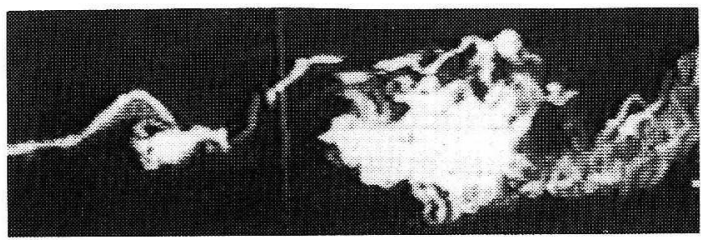

$t=t_{0}+1.4(\mathrm{~s})$

写真一1 渦の生成・合成

した結果，1 本のみのホット・フィルム流速計から得ら れる自己相関を Taylor の凍結乱流の仮説を適用して空 間相関に置換することはできないことが判明した。すな わち, 強いせん断効果と組織渦の存在する混合層では凍 結乱流の仮説が成立しないこと品が再確認された（図一 19).

主流方向に離れた 2 点間の組織渦の周波数帯の乱れの

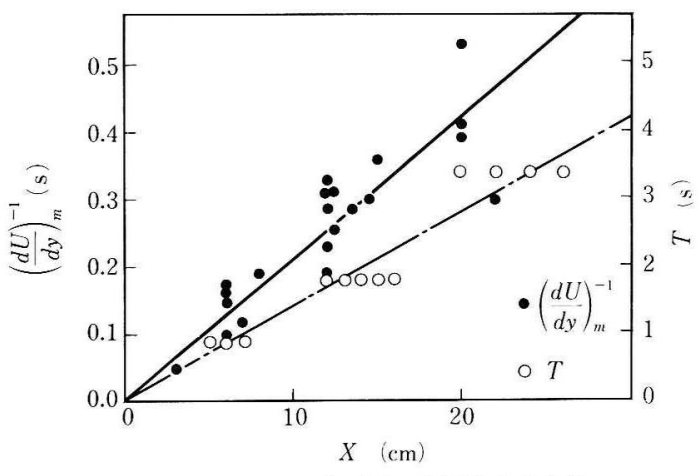

図一18 $\quad \boldsymbol{T}$ と $(\boldsymbol{d} U / \boldsymbol{d} \boldsymbol{y})_{m}^{-1}$ の流下方向の変化

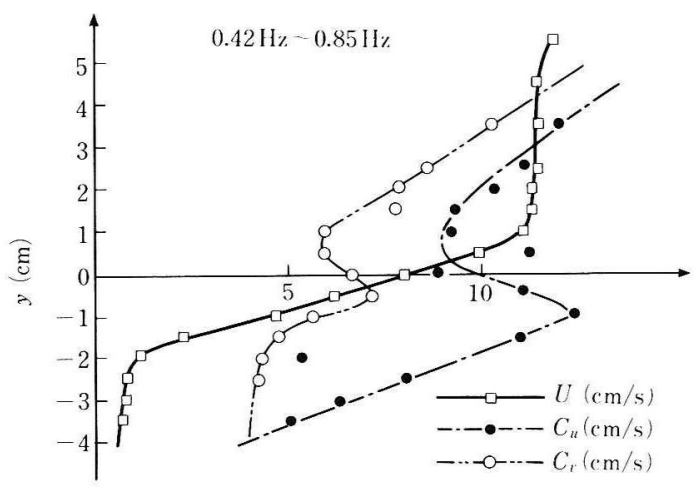

図一19 位相速度 $U, C_{u}, C_{v}$ の分布

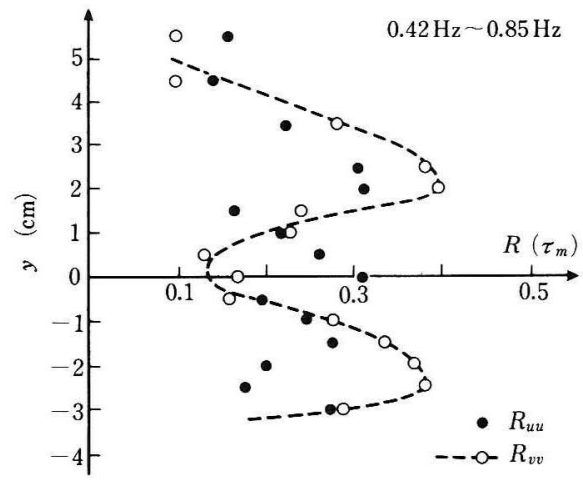

図-20 乱れの空間相関 $\boldsymbol{R}_{u u}, \boldsymbol{R}_{v v}$ の分布

相関は混合層の中心付近で弱く，中心から離れた上下層 で相関が強い（図一20）。これは上述の平均せん断によ る組織渦の分裂に関係している.

組織渦による流速変動は渦の中心付近では正弦波に近 い波形を示す。しかし混合層の上部領域では組織渦の周 波数より高い周波数の変動を示し，下方に向かうに従い 流下方向の流速変動は位相が少しずつ遅れ始め, 下部領 域では大きく遅れて位相が逆転する。一方，垂直方向の 速度変動のパターンは変わらず, 位相は 1 断面にわたつ 
てまったく変化しない（図一21）.

仮想界面変位を基準とした条件付きサンプリングによ り, 明確な組織構造と渦に伴う乱流特性量の空間構造が, 時間とともに移流してゆく様子が観測で明らかにされた (図一22).下層水が組織渦によって混合層へ侵入する 角度は $27 \sim 28^{\circ}$ である（図一23）。

組織渦は Kelvin・Helmholts の不安定性から生じ,

$y=0.75 \mathrm{~cm}$
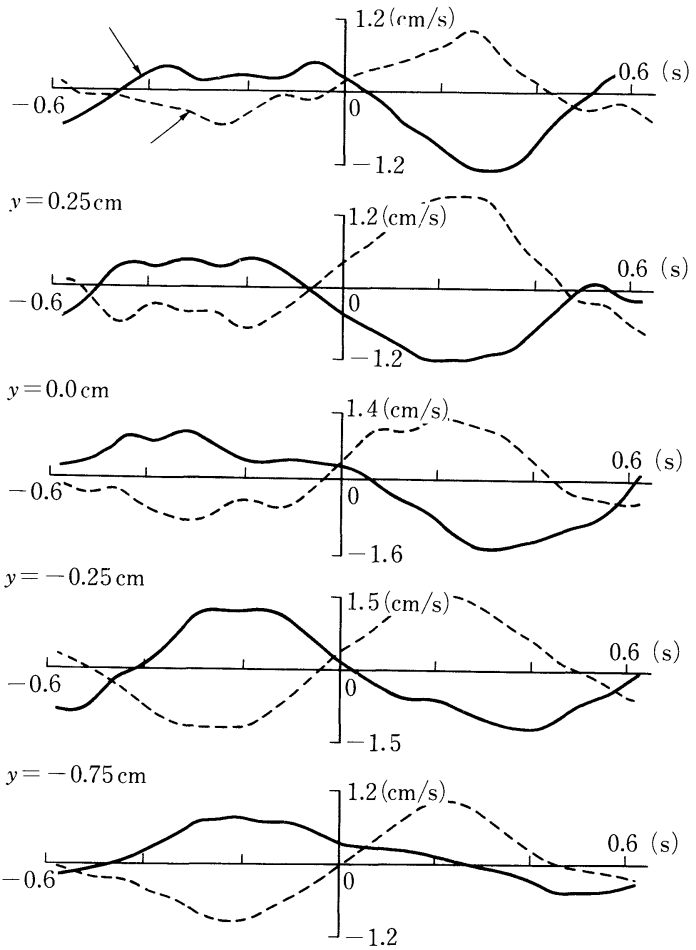

$y=-1.25 \mathrm{~cm}$

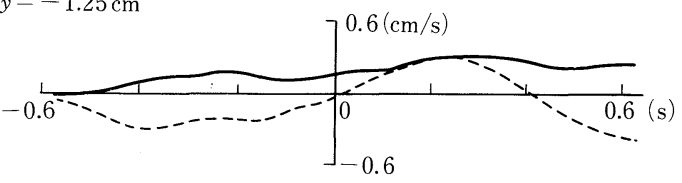

図一21 1 周期にわたる $\tilde{u}, \tilde{v}$
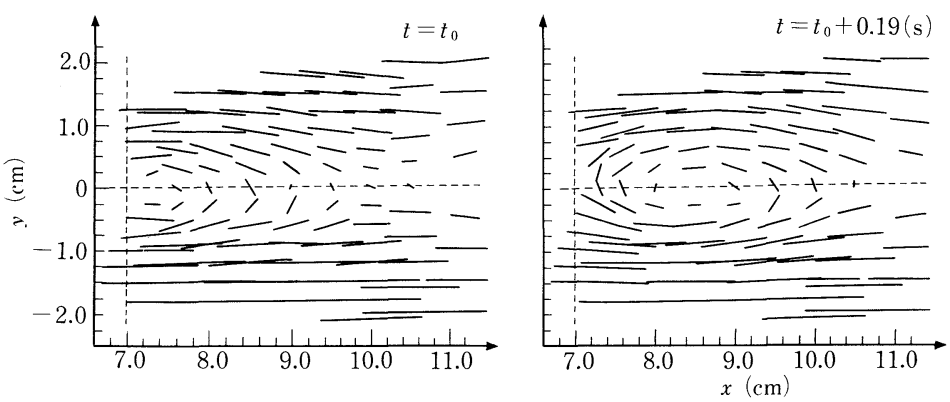

図一22 組織渦の時間変化

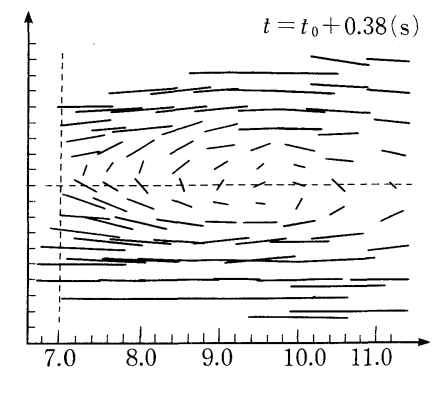

平均流から最初にエネルギーを手渡されるため, 乱れエ ネルギーの卓越した大規模渦としてせん断乱流場の構成 に寄与している．しかし，連行は組織渦のみによって決 まるのではなく，せん断乱流場全体が担っている．組織 渦はその周波数帯でレイノルズ応力に寄与しているが, 組織渦の存在自体は流れの中のレイノルズ応力を減少さ せ，平均流の安定化の方向に作用しており，之の働きが 組織渦の発生原因になっているものと思われる.

謝辞 本研究に際しては, 文部省科学研究費補助 金総合研究 $(A)$, 昭和 61 62 年度（研究代表者 玉井 信行，課題番号 61302061）の援助を受けた。

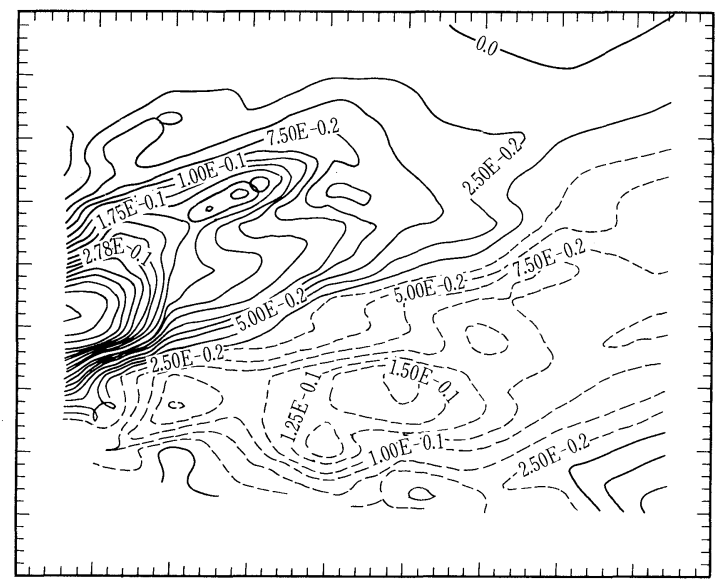

図一23 $\tilde{\rho}^{\prime}$ の空間分布 


\section{付録 乱流の組織構造の定義および関連する用 語の解説}

\section{（1）座標系ならびに流速および，長さスケール}

<座標 $>x$ 軸：流下方向 (streamwise)

$y$ 軸：鉛直方向 (vertical)

$z$ 軸：横断方向 (spanwise)

transverse $=$ cross-stream = lateral は spanwise と同 意味，normal は vertical と同意味. ただし， $y$ 軸方向 に重力が作用するものとする．重力方向（ $y$ 軸方向）を $z$ 軸にとる場合もあるが, Townsend $(1976)^{6)}$ の専門書 のみを除いて流体力学，特に乱流ではめったに使われな い. axial=longitudinal はstreamwise と同意味.

〈速度成分について>

直交座標のテンソル表示を使って次のように速度成分 を表わす。

$i$ 方向の速度 $\tilde{u}_{i}=U_{i}+u_{i}(i=1$ が $x$ 軸, $i=2$ が $y$ 軸, $i=3$ が $z$ 軸に相当する)

$\widetilde{u}_{i}=$ 瞬間流速 (instantaneous velocity)

$U_{i}=$ 平均流速 (mean velocity)

$u_{i}=$ 流速変動成分

(fluctuating component of velocity) $u_{i}^{\prime} \equiv \sqrt{u_{i}^{2}}$ 乱れ強度 (turbulence intensity)

$U_{\max }=$ 主流の最大流速

(maximum mainstream velocity)

$U_{m}=$ 断面平均流速 (bulk mean velocity)

従来，水理学では乱れ変動として $u_{i}^{\prime}$ を使うことが多 かったが, 流体力学, 特に乱流の分野では大文字は平均 成分值, 小文字は変動成分値を表わすことが定着した. このため, $u_{i}^{\prime}$ 之書くと $u_{i}$ の $\mathrm{rms}$ 值（標準偏差に相当す

る) すなわち乱れ強度を意味するから混乱を避けるべき である。

\section{（2）開水路乱流の領域区分}

鉛直方向の座標 $y$ を内部変数 $(U *$ と $\nu)$ および外部 変数 $\left(U_{\max }\right.$ と $\left.h\right)$ で次のように無次元化する.

$y^{+} \equiv y U_{*} / \nu$ (内部変数で無次元化 $)$

$\xi \equiv y / h$ (外部変数で無次元化)

$R_{*} \equiv h U_{*} / \nu=y^{+} / \xi$ はレイノルズ数

$\nu$ : 動粘性係数 (kinematic viscosity)

$U_{*} \equiv \sqrt{\tau_{0} / \rho}$ : 摩擦速度 (friction velocity)

$\tau_{0}$ : 壁面せん断応力 (wall shear stress)

領域 (Range)

領域の名称

$0<y^{+}<(5-10)$

粘性底層

(viscous sublayer)

$(5-10)<y^{+}<(30-40) \quad$ バッファ層（buffer layer)

$30<y^{+}<0.2 R_{*}$ $\xi<0.2$

$0.2<\xi \leqq 1$

$0.2<\xi<0.6$

$0.6<\xi \leqq 1$

$50<y^{+}<0.6 R_{*}$
対数則の成立範囲は $y^{+}$表 示ではレイノルズ数 $R *$ に 依存する

ウェイク領域

(wake region)

中間領域

(intermediate region)

自由水面領域

(free-surface region)

平衡領域

(equilibrium region)

平衡領域 : 乱れエネルギーの発生率 $G$ が乱れの 逸散率 $\epsilon$ (散逸率ともいう) とほぼ等 しくなる領域。

自由水面領域：逸散率（散逸率ともいう）が乱れの拡 散率とバランスする領域．鉛直方向の 乱れ強度 $v^{\prime}$ が自由水面のため抑制さ れる。

ウェイク領域：平均流速 $U^{+} \equiv U / U *$ が対数則からず れる領域

壁面領域 (wall region) : $y^{+}<100$ のバーストが顕著 な領域

内層（inner layer）：壁面領域と同意味

外層 (outer layer) : $y^{+}>100$

（3）乱流事象やプロセス

・事象 (event)：ある構造をもった流体運動.

・一連の事象 (sequence of events)：連続的に起こる 事象.

・コヒーレント (coherent) : 流机のある特性が空間的 時間的に相関をもつ性質.

・組織的 (organized) : coherent とほぼ同義.

・秩序的 (ordered)：coherent とほぼ同義. coherent，organized，および orderedには若干の二ュ アンスの違いがあるが，ほぼ同義であり，現在 coherent が最も多く用いられる.この邦訳として,“組織的” を推奨する，たとえば， coherent structure は組織構 造と訳す。

・プロセス (process)：ある方法で関係づけられる一連 の事象.

・ inactive 運動＝乱れエネルギーには寄与するが，レイ ノルズ応力には寄与しない運動で, 上流の流れの履歴 (flow history) に影響される運動.たとえば非定常 流の低周波変動や流れ之波の共存場に顕著に現われ る.

・ active 運動＝レイノルズ応力に寄与する運動，すなわ ち，局所場のシアー（流速勾配のことをいう）に関係 づけられるもので, 代表例に渦動粘性モデルがある. 
この用語はあまりなじみがないかもしれないので参考 文献を挙げる.

“active-inactive 運動” の定義は Bradshaw (1967) ${ }^{54)}$ が 考案したもので, 特に flow history の乱れに及ぼす影 響を評価する目的で定義されたものである.

- 内部変数 (inner variables) 速度 $=U_{*}$, 長さ $=\nu / U_{*}$, 時間 $=\nu / U_{*}^{2}$

- 外部変数 (outer variables) 速度 $=U_{\max }\left(\right.$ ときには $U_{*}$ も使う $)$, 長さ=開水路で は水深 $(h)$, 境界層では $\delta, \delta^{*}, \theta$ を使う.

\section{(4) 渦, 組織渦および渦構造}

-渦 (vortex)：ある面に流線（定常・非定常にかかわ らず)を射影したとき, 閉曲線（大雑把には円形）を 形成する流体塊.

・渦 (eddy) : vortex と同意義であるが，より日常語に 近い. vortex の方が eddy より組織的構造をもってい るとのニュアンスがある.

- 渦度 (vorticity) : $\omega_{i}=\epsilon_{i j k} \partial u_{k} / \partial x_{j}$ or $\boldsymbol{\omega}=\nabla x \boldsymbol{u}$ (流 体運動の性質の数学的定義で, ベクトル解析では回転 (rotation) という3․) 渦 (vortex) は必ずしも乱流 ではない，渦度があってはじめて乱流という。たとえ ば, 自由渦 (free vortex) はポテンシャル流での渦で あるが，乱流ではない。

・渦線 (vortex line) : 渦度ベクトル $\omega_{i}$ に平行な線.

・渦曲面 (vortex sheet) : 渦線で構成された曲面.

・渦管 (vortex tube)：渦線で構成された閉じた管.

- 循環 (circulation) : $\Gamma=\int U_{i} t_{i} d s （ t_{i}$ は単位接線べ クトル).

-エンストロフィー (enstrophy) : $E \equiv\left(\omega_{1}^{2}+\omega_{2}^{2}+\omega_{3}^{2}\right) / 2$ と定義され, 乱れエネルギー $k \equiv\left(u_{1}^{2}+u_{2}^{2}+u_{3}^{2}\right) / 2$ に対 応する。

・ロールセル (roll cell) : 強い渦度集中を伴わないゆっ くりと回転運動する流体塊.

・馬蹄型渦 (horseshoe vortex)：へ形をした渦管で, 2 つの脚 (leg) と1つの頭 (headあるいはtip) から 構成されている.

Theodorsen $(1955)^{55)}$ の命名.

・ヘヤピン渦 (hairpin vortex) : 馬蹄型渦とほぼ同形で あるが, レイノルズ数が大きいとき馬蹄型渦が引き伸 ばされたもの.

Willmarth and Tu $(1967)^{56)}$ の命名.

・ループ渦 (loop vortex) :ヘヤピン渦と同義.

Head and Bandyopadhyay (1981) $)^{57)}$ や Grass $(1983)^{58)}$ の命名.

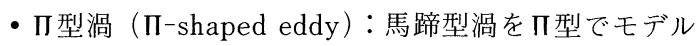
化したもの.

Black $(1968)^{59)}$, Nakagawa and Nezu $(1974)^{60)}$ の命名.
・ $\Omega$ 型渦 $(\Omega$-shaped eddy) : 馬蹄型を $\Omega$ 型でモデル化 したもの.

Hinze $(1975)^{5)}$ や Kim and Moin $(1986)^{61)}$ の命名.

- $\Lambda$ 型渦 $(\Lambda$-shaped eddy) : 馬蹄型を $\Lambda$ 型でモデル化 したもの.

Perry ら $(1982)^{62)}$ の命名であり, 乱流班点 (turbulent spot）が現われる層流から乱流への遷移の渦構造をよ くモデル化している.

・リング状の渦 (ring vortex)：ほぼ円形をした渦輪.

・ボイル渦 (boil vortex) : 自由水面に現われた渦輪で, いろいろな生成因をもつ渦の先端が水面に達して形成 される.

その発生原因によって 3 種類に大別される ${ }^{36)}$.

-第 1 種のボイル (boil of the first kind) : 河床波背後 やステップ剥離流の再付着点付近から発生する渦度集 中の大きい渦（コルク渦という）が発達し，水面まで 達したもの.

- 第 2 種のボイル (boil of the second kind) : 水深規模 のセル状の 2 次流群 (縦渦) の上昇流が水面まで達し たもの.

・第 3 種のボイル (boil of the third kind) : 壁面での バーストが水面まで達したもの. 低レイノルズ数の流 れで顕著にみられる.

・らせん渦 (spiral vortex)：path line や流線がらせん 運動をする渦.

・反回転の渦対 (counter-rotating vortex pair) : 2 つの ほぼ平行した, 互いに逆向きの回転をする (相互作用) 渦. Taylor-Görtler 渦, バーストに伴う縦渦, 並列 らせん流 (2 次流群) に伴う縦渦が有名.

・縦渦 (longitudinal vortex) : 渦管が主流方向を向い た渦. 反回転方向の渦対で構成される.

- 自己誘導 (self-induction) : 周用流体との相互作用で 起こる渦中心の運動, すなわちビオ・サバールの法則 が成立する.

・相互誘導 (mutual induction)：他の渦によって引き 起こされる渦中心の運動.

・渦のペアリング (vortex pairing)：渦が相互に干渉し て相互誘導を行うこと. 渦の合体へ移行することが多 い.

-渦の合体 (vortex coalescence) : 2つの渦が合体して 1 つの渦になること.

・移流 (advection or convection)：ほぼ平均流で流下 方面に移動する量（スカラーもしくはベクトルの運 動).

- 凍結乱流 (frozen turbulence) : 乱流構造が何の変形 もなしにあたかも凍結したような状態で移流されるこ と. Taylor $^{63)}$ によって提案された, 格子乱流で適用 
される仮説である. せん断乱流では厳密には成立しな い，適用条件として Lin $(1953)^{53)}$ の理論がある.

\section{（5）組 織構造}

-低速縞（low-speed streak）：粘性底層内で平均流速 より低速な，流下方向に組織立った領域.

- 縞構造 (streaky structure)：低速縞と高速縞とが横 断方向に交互に配置された構造.

- 低速縞の浮上 (lifted low-speed streak) : 壁面から $y^{+}>10$ の上方に浮上する低速縞.

- 低速縞の摇動（low-speed streak oscillation）：低速 縞が三次元的に摇動すること.

・エジェクション (ejection) : 急激な低速縞の浮上を いい, 上方の高速流体中へ激しく噴出し, 乱れを生成 する.

・スウィープ (sweep)：高速流体が上流から壁面側に 侵入する組織運動. 最近の三次元計測によると, 渦系 が上流側下方へ引き伸ばされるときに，スウィープ型 の信号が検出されるという結果もある ${ }^{16)}$.

- 解体 (breakup)：小規模な，秩序のない力オス運動 へと移る組織渦の崩壊.

・崩壊 (breakdown) : activeな組織構造が消滅するこ と.これは breakup やその他で起こる. breakup も breakdown も組織渦のエネルギーが微細渦へと輸送 され（カスケード過程という），最終的に熱逸散（熱 散逸ともいう) (dissipation into heat) される.

- 4 象限区分運動（quadrant motion）：瞬間レイノルズ 応力 $-u(t) \cdot v(t)$ を 4 象限に区分すること.

$\operatorname{RS}_{1}(u>0, v>0)=$ outward interaction

$\operatorname{RS}_{2}(u<0, \quad v>0)=$ ejection-like motion

$\mathrm{RS}_{3}(u<0, \quad v<0)=$ inward interaction

$\mathrm{RS}_{4}(u>0, \quad v<0)=$ sweep-like motion

の 4 象限運動がある ${ }^{64), 21)}$. あるしきい值 $|u v|>$ $H \cdot u^{\prime} v^{\prime}$ を設けると(ここでしきい值 $H$ のことを hole 值という), $\mathrm{RS}_{2}$ が ejection に, $\mathrm{RS}_{4}$ が sweep に対応した組織運動を表わす。

・バースト (burst)：ある特定の領域で平均值よりも ずっと強い乱れエネルギーやレイノルズ応力を発生さ せる間欠的な一連の事象で, バースティングともいう. バーストは低速縞の lift-up, oscillation, ejection そ して sweep の一連の流体運動をいう.

-viscous super-layer：乱流/非乱流界面の粘性に支配 された外層面で, ごくうすい層.

- bulge 運動：境界層端の乱流/非乱流の凸凹状をした 界面の大規模な組織構造. bulge とは非乱流部（渦度 がゼロとなるポテンシャル流）が乱流部に張り出して いることを意味する. bulge 運動は間欠因子によって 検出される. 外部変数で支配され, 開水路流れのボイ
ル渦に対応する.

a) 乱流の専門書

1) Monin, A.S. and Yaglom, A.M. : Statistical Fluid Mechanics, MIT Press, Vol.1, 1971.

2) Monin, A.S. and Yaglom, A. M. : Statistical Fluid Mechanics, MIT Press, Vol.2, 1971.

3) Tennekes, H. and Lumley, J. L. : A First Course in Turbulence, MIT Press, 1972.

4) Rotta, J. C. : Turbulente Strömungen, Teubner, 1972 (大路通雄訳 : 乱流, 岩波書店, 1975).

5) Hinze, J. O. : Turbulence (2nd. ed.), McGraw-Hill, 1975.

6) Townsend, A.A. : The Structure of Turbulent Shear Flow (2nd ed.), Cambridge University Press, 1976.

7) Prandtl, L. : Further durch die Strömungslehre, Friedr. Vieweg \& Sohn, 1965 (白食ほか訳: 流れ学, 上, 下, コロナ社, 1974).

8) Rouse, H. : Advanced Mechanics of Fluids, 1959.

9) Schlichting, H. : Boundary Layer Theory (7th. ed.), McGraw-Hill, 1978.

10）谷一郎編：流体力学の進歩 - 乱流, 丸善, 1980.

11）谷 一郎編：流体力学の進歩・境界層, 丸善, 1984.

12）日本流体力学会編：流体力学ハンドブック, 丸善, 1987 .

13）巽 友正編：乱流現象の科学, 東京大学出版会, 1986.

b) 参考論文

14) Kim, J., Moin, P. and Moser, R. : Turbulence Statistics in Fully Developed Channel Flow at Low Reynolds Number, J. Fluid Mech., Vol.177, pp. 133 166, 1987.

15) Luchik, T.S. and Tiederman, W. G. : Timescale and Structure of Ejections and Bursts in Turbulent Channel Flows, J. Fluid Mech., Vol.174, pp. 529 552, 1987.

16）西野・笠木：3 次元画像処理流速計による 2 次元チャネ ル乱流の乱流統計量の測定, 日本機械学会論文集 B 編, Vol.56, No. 525, pp. 1338 1347, 1990.

17) Nakagawa, H. and Nezu, I. : Structure of Space-Time Correlations of Bursting Phenomena in an Open-Channel Flow, J. Fluid Mech., Vol. 104, pp. 1 43, 1981.

18) Cantwell, B. J. : Organized motion in turbulent flow, Ann. Rev. Fluid Mech., Vol. 13, pp. 457 515, 1981.

19) Wallace, J.M. : The Vortical Structure of Bounded Turbulent Shear Flow, Flow of Real Fluids (ed. Meier, G.E. A. and Obrmeier, F. ), Lecture Notes in Physics, No. 235, Springer-Verlag, pp. 253 268, 1985.

20) Nakagawa, H. and Nezu, I. : Bursting Phenomenon Near the Wall in Open-Channel Flows and Its Simple Mathematical Model, Memoirs, Faculty of Eng., Kyoto University, Vol.40, pp. 213 240, 1978.

21) Nakagawa, H. and Nezu, I. : Prediction of the Contributions to the Reynolds Stress from the Bursting Events in Open Channel Flows, J. Fluid Mech., Vol. 99 $\sim 128,1977$.

22) Blackwelder, R.F. and Haritonidis, J.H. : Scaling of the Bursting Frequency in Turbulent Boundary Layers, 
J. Fluid Mech., Vol.132, pp. 87 103, 1983.

23) Willmarth, W. W. and Sharma, L. K. : Study of Turbulent Structure with Hot Wires Smaller Than the Viscous Length, J. Fluid Mech., Vol. 142, pp. 121 149, 1983.

24) Acarler, M.S. and Smith, C. R. : A Study of Hairpin Vortices in a Laminar Boundary Layer. Part 2. Hairpin Vortices Generated by Fluid Injection, J. Fluid Mech., Vol. 175, pp. 43 83, 1987.

25）大成・佐賀 - 斉藤：開水路乱流内の縦渦構造, 土木学会 論文集, No. 363, pp. 135 144, 1985.

26）佐賀 - 大成 - 渡辺 - 斉藤 : 開水路乱流内層の渦構造と流 速波形の相互関係, 土木学会論文集, No. 393, pp.131 140, 1988.

27) Blackwelder, R.F. and Kaplan, R.E. : On the Wall Structure of the Turbulent Boundary Layer, J. Fluid Mech., Vol.76, pp. 89 112, 1976.

28）木下: 航空写真による洪水流解析の現状と今後の課題, 土木学会論文集, No. 345, pp. 1 19, 1984.

29) Wolman, M. G. and Brush, L. M. : Factors Controlling the Size and Shape of Stream Channels in Coarse Noncohesive Sands, Geological Survey Professional Paper, 282-G, 1961.

30）木下：並列らせん流に関する実験的研究，昭和 51 年度北 海道開発局石狩川開発局建設部委託調査報告書, 北海道 開発局石狩川開発建設部, 1977.

31）中川・慗津・富永：開木路流れにおける横断方向の縞構 造と大規模乱流, 土木学会論文集, No. 312, pp. 93 105, 1981.

32）大本 -平野 : 縦筋河床の形成領域之掃流力の分布特性に 関する研究, 土木学会論文集, No. 399, pp. 75 84, 1988.

33）林・大橋 - 小谷：開水路流れにおける縦渦の乱流特性に ついて, 第 28 回水理講演会論文集, pp. 263 269, 1984.

34）林・南橋 - 大橋：開水路大規模乱流の時空間構造に関す る研究, 中央大学理工学部紀要, Vol. 29, pp. 223 254, 1986.

35) Pauley, W. R. and Eaton, J. K. : Experimental Study of the Development of Longitudinal Voltex Pairs Embedded in a Turbulent Boundary Layer, AIAA Journal, Vol. 26, No.7, pp. 816 823, 1988.

36) Nezu, I. and Nakagawa, H. : Turbulent Structure of Backward-Facing Step Flow and Coherent Vortex Shedding from Reattachment in Open-Channel Flows, Turbulent Shear Flows 6 (ed. Whitelaw, J.H. et al.), Springer-Verlag, Vol.6, pp.313 337, 1988.

37）金澤・中川・穪津：段落ち下流の組織渦と変動特性に関 する研究, 土木学会年講, II-169, pp. 370 -371, 1988.

38) Muiller, A. and Gyr, A. : On the Vortex Formation in the Mixing Layer Behind Dunes, J. Hydraulic Research, Vol.24, pp.359 375, 1986.

39) Coleman, J. M. : Brahmaputra River; Channel Process and Sedimentation, Sediment. Geol., Vol.3, pp.129 239, 1969.

40) Nezu, I. and Nakagawa, H. : Accurate Measurements of Space-Time Correlations of Coherent Vortex behind Dunes in Turbulent Open-Channel Flows with Combina- tion of Laser-Doppler Anemometer and Hot-Film Anemometer, Proc. of Instrumentation for Hydraulic Laboratories, Canada Centre for Inland Waters, pp. 29 44, 1989.

41) Ikeda, S. and Asaeda, T. : Sediment Suspension with Rippled Bed, J. Hydraulic Eng., ASCE, Vol.109, pp. 409 423, 1983.

42) Tamai, N., Asaeda, T. and Ikeda, H. : Study on Generation of Periodical Large Surface Eddies in a Composite Channel Flow, Water Resources Research, Vol.22, No. 7, pp. 1129 1138, 1986.

43）今本・石垣・木下: 複断面開水路流れの水理特性につい 乙 (2), 京都大学防災研究所年報, No. 27 B-2, pp. 1129 1138, 1986.

44) Tominaga, A., Ezaki, K. and Nezu, I. : Turbulent Structure in Compound Channel Flows with Rectangular and Trapezoidal Main Channel, Proc. of 3rd Int. Symp. on Refined Flow Modelling and Turbulence Measurement, IAHR, Tokyo, pp. 511 518, 1988.

45) Tamai, N., Asaeda, T. and Tanaka, N. : Vortex Structures around a Hemispheric Hump, Boundary-Layer Meteorology, Vol. 39, pp. 301 314, 1987.

46) Acarlar, M. S. and Smith, C. R. : A Study of Harirpin Vortices in a Laminar Boundary Layer. Part 1: Hairpin Vortices Generated by a Hemisphere Protuberance, J. Fluid Mech., Vol. 109, pp. 409〜423, 1983.

47）福岡・福島・奥津：大規模渦によって誘起される上昇流 およびボイルの構造, 土木学会論文集, No. 298, pp. 41 〜52, 1980.

48）池田・大迫・浅枝・玉井：開水路流れ中の下り斜面上を 流下する鉛直渦と上昇流，第 19 回乱流シンポジウム講演 論文集，pp. 210～214，1987.

49）小松・柴田・小坪・行徳：混合せん断流における大規模 渦と乱狆の特性, 第 29 回水理講演会論文集, pp. 791 796, 1985.

50）小松・梅永：混合せん断流における大規模渦の特性とそ の水理学的役割, 第 30 回水理講演会論文集, pp. 667 $672,1986$.

51）小松・山本・梅永：混合せん断流における大規模渦の時 空間構造とその水理学的役割, 土木学会論文集, No. 405, pp. 89 97, 1989.

52）小松・山本・柴田・粟谷：混合せん断流における大規模 渦に関する実験的研究, 第 33 回水理講演会論文集, pp. $577 \sim 582,1989$.

53) Lin, C. C. : On Taylor's Hydpothesis and the Acceleration Terms in the Navier Stokes Equation, Quar. of Applied Math., Vol.10, pp.295 306, 1953.

54) Bradshaw, P. : 'Inactive' Motion and Pressure Fluctuations in Turbulent Boundary Layer, J. Fluid Mech., Vol. 30, pp. 241 258, 1967.

55) Theodorsen, T. : The Structure of Turbulence, 50 Jahnre Grenzschichtforschung (ed. Görtler, H. and Tollmien, W. ), Friedr. Vieweg \& Sohn, pp. 55 62, 1955.

56) Willmarth, W. W. and Tu, B. J. : Structure of Turbu- 
lence in the Boundary Layer near the Wall, Phys. of Fluids, Vol.10, pp. S 134 S 137, 1967.

57) Head, M. R. and Bandyopadhyay, P. : New Aspects of Turbulent-Boundary Structure, J. Fluid Mech., Vol. 107, pp. 297 338, 1981.

58) Grass, A. J. : The Influence of Boundary Layer Turbulence on the Mechanism of Sediment Transport, Mechanics of Sediment Transport (ed. Sumer, B. M. and Müller, A. ), Balkema, pp.3 17, 1983.

59) Black, T. J. : A New Model of the Shear Stress Mechanism in Wall Turbulence, AIAA 6th Aero. Sci. Meeting, AIAA Paper No.68, 1968.

60) Nakagawa, H. and Nezu, I. : On a New Eddy Model in Turbulent Shear Flow, 土木学会論文集, No.231, pp. $61 \sim 70,1974$.
61) Kim, J. and Moin, P. : The Structure of the Vorticity Field in Turbulent Channel Flow. Part 2. Study of Ensemble-Averaged Field, J. Fluid Mech., Vol. 162, pp. 339 369, 1986.

62) Perry, A.E. and Chong, M.S. : On the Mechanism of Wall Turbulence, J. Fluid Mech., Vol.119, pp.173 217, 1982.

63) Taylor, G. I. : Statistical Theory of Turbulence, Proc. Roy. Soc. London, Series-A, Vol. 151, pp.421 478, 1935.

64) Lu, S. S. and Willmarth, W. W. : Measurements of the Structure of the Reynolds Stress in a Turbulent Boundary Layer, J. Fluid Mech., Vol.60, pp. 481 511, 1973.

(1990.9.10 • 受付) 